\title{
Structural biology gets UK funding boost
}

[LONDON] The UK government's Biotechnology and Biological Sciences Research Council (BBSRC) is to provide $£ 8.5$ million (US\$12.75 million) to help to set up multidisciplinary centres and to update equipment in structural biology research, in which it says Britain is now second only to the United States.

The funds will be released over three years, and are being allocated in response to a review by the research council of structural biology research, published last week. This warns that the United Kingdom could lose its pre-eminent position in the discipline without greater collaboration between universities, and between universities and industry.

"Much of biology is changing; it is becoming a 'big science' which needs stateof-the-art equipment and can no longer be effectively carried out by small, isolated teams," says Chris Higgins, professor of clinical biochemistry at the University of Oxford, who chaired the BBSRC review. Other members of the panel included representatives from public and private funding agencies in the United Kingdom, the United States and Europe.

The multidisciplinary centres will be formed in partnership between the BBSRC, universities and the pharmaceutical industry, which is becoming increasingly dependent on research into the structure and function of biological molecules. Higgins says he hopes the extra funds can be matched by industry and other sources. A call for

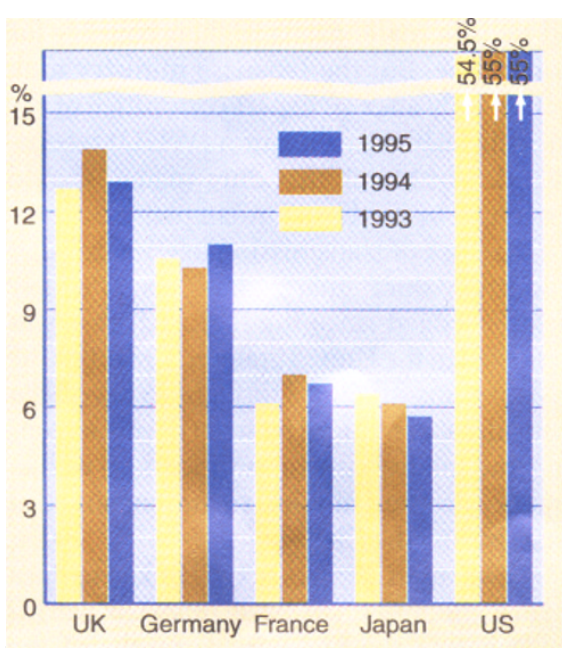

Percentage shares of world output in structural biology, weighted for 'quality'.

proposals for the new research centres is being issued this week.

"We need a limited number of centres that provide both a focus for high quality research and access for other biology researchers. We want to avoid every university setting up structural biology departments," says Higgins. Colin Miles, head of the biomolecular sciences group at the BBSRC, says "the centres need not be bricks and mortar at a single location" - they could be "virtual centres".

The new funds will supplement the BBSRC's current $£ 17-£ 20$ million annual spending on structural biology, 10 per cent of the council's total budget for biology research. A similar sum is spent by the Medical Research Council. Between them, the funding councils account for 80 per cent of UK spending on structural biology. The BBSRC has already spent $\mathfrak{E} 5$ million on new equipment.

The council's report contains detailed bibliometric information on world structural biology research. Higgins describes it as "one of the most comprehensive and thorough surveys of any research discipline". It finds that the United Kingdom leads Europe in structural biology research, with the UK share of world output increasing steadily from 9 per cent in 1986 to 12 per cent in 1995.

Universities account for 70 per cent of research output, with research council institutes at just under 17 per cent and industry on 5.6 per cent. Structural biology research is concentrated at a handful of institutions. Just five - Oxford, Cambridge, Birkbeck (London), York and University College London - out of the United Kingdom's 140 universities account for 50 per cent of output.

The report points out that access to a synchrotron radiation facility is essential for structural biology. UK researchers now rely on the synchrotron radiation source at the Daresbury Laboratory in Warrington, Cheshire, a facility that will outlive its usefulness in three years. The BBSRC has not yet decided whether to find the $£ 15$ million needed to help finance a new source. Ensan Masood

\section{Korea leaps before it looks over gene therapy guidelines}

[TOKYo] In an unusual move, a group of medical researchers in Seoul is expected to announce this week that they have carried out the first clinical application of gene therapy in South Korea. The announcement is surprising because South Korea, unlike most industrialized countries, has yet to establish guidelines for gene therapy.

Treatment began last month on a 33year-old woman suffering from breast cancer at Samsung Medical Center, a lavish new hospital set up by the South Korean industrial conglomerate.

The programme involves a retroviral vector from the United States, and is a collaboration between researchers at the centre, led by Chan H. Park, a group at Seoul National University under Sunyoung Kim, and a group at the University of Pittsburgh Medical Center led by Michael Lotze.

Using a protocol originally developed by Lotze's group, skin fibroblasts from the patient were treated with a retrovirus containing the gene for interleukin-12, an agent believed to activate immune defences against cancer cells. Cells containing the gene were then injected into the patient after irradiating them to stop them multiplying and overproducing interleukin-12, which can have toxic side-effects.

The proposal for the clinical trial went through three review steps over about 18 months. The protocol was first considered by an institutional review board at the Samsung Medical Center, then an ad hoc committee at the Ministry of Health and Social Welfare. Finally, the US Food and Drug Administration checked the protocol before approving the export of the genecarrying retrovirus.

But unlike the United States and Japan, where the first applications of gene therapy went through exhaustive public debate and examination by committees of the ethical and social implications of gene therapy as well as its medical aspects, South Korea is still in the process of setting up guidelines for gene therapy. The issue has been publicly debated for several years, but a government committee to set up guidelines was established only about two months ago, according to $\mathrm{Kim}$, and it will be some time before they are approved.

Park says the government process was taking "too long". He argues that the protocol has already been extensively reviewed in the United States, and that its safety is therefore well established. He also says it would "not be fair to be left behind" because of the lack of government regulations, and argues that the trial has undergone extensive domestic as well as international review.

Both Kim and Park expect their announcement to be welcomed by the Korean public, a view echoed by other Korean medical researchers. Koreans are "less concerned" and "less aware" of any potential problems associated with gene therapy, says one professor at Seoul National University. But he admits to a concern that the announcement may generate strong competition among Korean clinicians "without consideration of ethical and scientific problems". Daud Swmbenks 